\title{
Serum hepatitis as a persistent infection
}

\author{
YVONNE E. COSSART \\ From the Central Public Health Laboratory, London
}

Large amounts of serum hepatitis virus are circulating in the blood of about 50000 healthy persons in this country, and every year this agent causes at least 2000 cases of acute infection in adults. Superficially at least this resembles the ecological situation in a mouse colony recently affected by lymphocytic choriomeningitis. In situations where the carrier rate is 10 or even 100 times higher than in Britain, clinical serum hepatitis is reputed to be uncommon (Cherubin, 1971) suggesting an ecological comparison with a mouse colony where lymphocytic choriomeningitis is well established. Is there also a useful analogy to be drawn between the pathogenesis of lymphocytic choriomeningitis in the mouse and serum hepatitis in man?

While lymphocytic choriomeningitis can be grown in tissue culture and in eggs, and antibody to it measured in a variety of ways, the serum hepatitis virus has not yet been cultivated in vitro, nor is there any satisfactory test of immunity. The discovery of Australia antigen by Blumberg, Alter, and Visnich in 1965 , and the subsequent realization that its presence in the blood correlated closely with viraemia (Prince, 1968) has provided the first useful laboratory marker for the study of serum hepatitis.

\section{Acute Infection}

After inoculation of a susceptible adult both serum hepatitis virus and Australia antigen disappear and have not been identified in blood or tissues during the long incubation period. This stage varies from about four to 20 weeks, and its duration does not seem to be closely related either to the size of the infecting dose (Drake, Barondess, Bashe, Henle, Henle, Stokes, and Pennell, 1953) or to the particular strain involved (Murray, Diefenbach, Ratner, Leone, and Oliphant, 1954). Australia antigen, and infectivity, tend to appear in the blood a few days before the onset of illness, and this viraemic phase may persist for weeks or even months, especially in immunosuppressed individuals. Characteristically joint pain and swelling and a diffuse skin rash also appear at this stage, but these 'allergic' symptoms subside as jaundice develops.

The titre of the antigen in the blood rises very rapidly and has usually reached its maximum by the time the first serum sample is obtained from a patient with hepatitis. Titres of $1 / 1024$ or $1 / 2048$ in the complement-fixation test are not unusual, and correspond to infectivity titres of about $10^{6}$ ID $_{50}$ per millilitre of blood (Barker, Shulman, Murray, Hirschman, Ratner, Diefenbach, and Geller, 1970).

The exact nature of Australia antigen remains unknown but its morphological appearance in the electron microscope is sufficiently characteristic to provide a useful diagnostic feature (Bayer, Blumberg, and Werner, 1968). Three types of particle are seen (Fig. 2): small spherical particles about $20 \mathrm{~nm}$ in diameter, long particles of about the same diameter, and larger double-shelled particles about $40 \mathrm{~nm}$ in diameter (Dane, Cameron, and Biggs, 1970). There is no correlation between the proportions of these types of particle and the stage of the disease. The small round particles are always the most numerous, and their concentration has been estimated as about $10^{12}$ per millilitre (Almeida, Zuckerman, Taylor, and Waterson, 1969). Although they are roughly the size expected for the serum hepatitis virus itself (McCollum, 1952) they band on ultracentrifugation in calcium chloride at a density between 1.2 and 1.29 (Barker, Smith, Gehle, and Shulman, 1969; Gerin, Purcell, Hoggan, Holland, and Chanock, 1969). This means that they cannot contain significant amounts of nucleic acid if, as would be expected from their shape, they are constructed from protein subunits according to an icosohedral pattern. The density of both the larger particle types is of the same order. Great difficulties have been encountered in purifying Australia antigen, and until these are resolved the single report (Józwiak, Košcielak, Madeliński, Brzosko, Nowosławski, and Kloczewiak, 1971) of finding $5 \%$ RNA content cannot be accepted without reserve. It seems reasonable to speculate that Australia antigen may be a reconstitution product formed by aggregation of excess virus-coded protein units around polyanions such as phospholipids in serum (Cossart and Field, 1970).

The production of large amounts of nonreplicating viral antigen has been proposed to account for the induction of the state of 'split tolerance' in adult mice 
infected with very large doses of lymphocytic choriomeningitis virus (Hotchin, 1971). It is surprising to find that such very large amounts of Australia antigen can circulate in serum hepatitis without inducing an obvious antibody response, and it will be of great interest to see if this is also the result of the specific inhibition of immunity.

The production of acute disease in lymphocytic choriomeningitis is attributed to the cellular immune response of the adult animal, and the histological appearance is of widespread lymphocytic infiltration of the viscera (Findlay and Stern, 1936), all of which contain large amounts of virus. In serum hepatitis there is moderate periportal lymphocytic infiltration in the liver, but in other organs this is relatively minor (Lucké, 1944). Nothing is known about the distribution of infectious virus in the body. Australia antigen has been sought directly and by immunofluorescence in the liver, bone marrow, and other tissues such as the testis (Millman, Zavatone, Gerstley, and Blumberg, 1969; Nowosławski, Brzosko, Madaliński, and Krawczyński, 1970). The findings have been equivocal (Nielsen and Elling, 1971) and studies on the urine and faeces have also yielded negative or doubt-

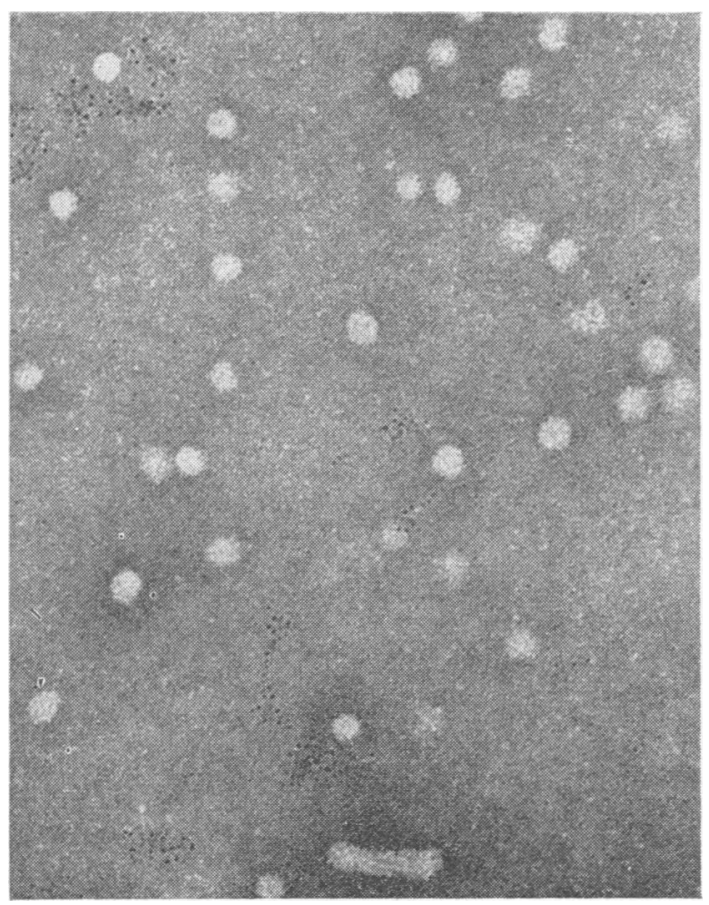

Fig. 1 Scattered Australia antigen particles. $\times 180000$. Prepared by negative staining with phosphotungstic acid after centrifugation at $40000 \mathrm{~g}$ for one hour. (Figs. 1 and 2 kindly supplied by Dr Anne Field.) ful results (Grob and Jemelka, 1971; Apostolov, Bauer, Selway, Fox, Dudley and Sherlock, 1971; Gust, Kaldor, and Nastasi, 1971; Tripatzis and Horst, 1971).

Beyond the observation that antigen inadvertently transfused into a patient is cleared from the blood within a few days, little is known about the metabolism of Australia antigen and nothing about its origin.

Some reports have now appeared of finding masses of small, virus-like particles in the nuclei, and, to a lesser extent, in the cytoplasm of liver parenchymal cells in some patients with serum hepatitis (Scotto, Stralin, and Caroli, 1971).

It is tempting to believe that these may indeed be the infective agent which has eluded discovery for so long. Whether the liver damage is due to the direct cytopathic effect of such an agent remains doubtful, since intracellular virus particles are not a feature of the fine structure of lesions in the hepatitis of glandular fever or cytomegalovirus infection(Wills, 1972). In both these diseases immunopathology might also be suspected.

Australia antigen particles in the serum are some-

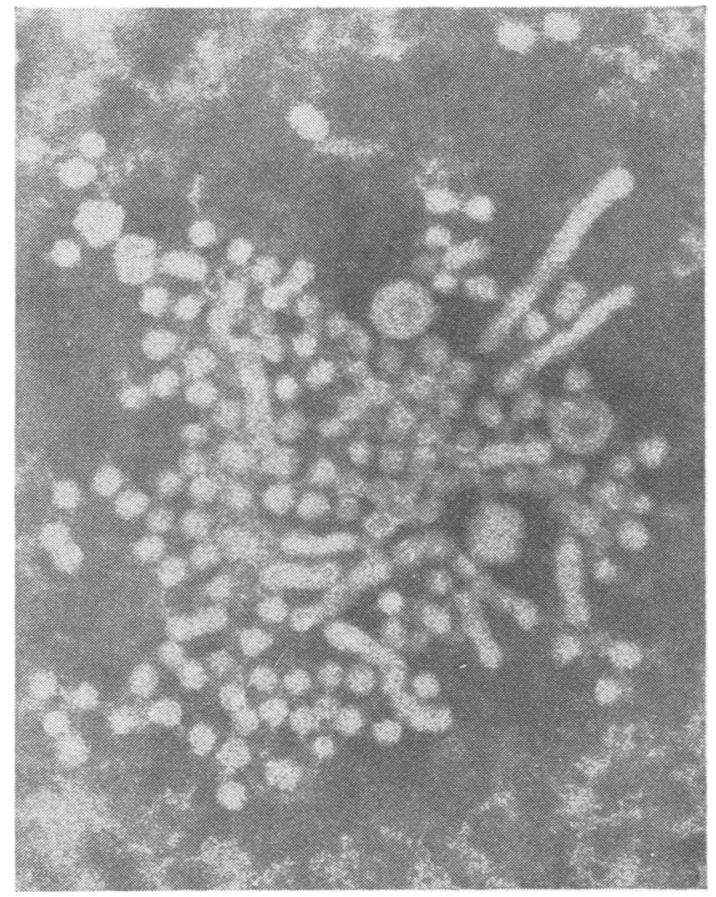

Fig. 2 A clump of Australia antigen particles showing all three types. $\times 180000$. Prepared by negative staining with $3 \%$ phosphotungstic acid after centrifugation at $40000 \mathrm{~g}$ for one hour. 
times found aggregated into clumps which closely resemble immune complexes (Figs. 1 and 2) made in vitro by mixing the antigen with its corresponding antibody (Almeida and Waterson, 1969). These clumps may occur transiently during the acute stage of hepatitis and these authors have suggested that they are involved in the mechanism of liver damage. A similar suggestion has also been made by Nowoslawski et al (1971) and by Shulman and Barker (1969) who observed transient anti-complementariness in sera obtained from patients just before or at the same time as jaundice appeared.

So far, however, there are a number of difficulties in ascribing a major role to these complexes in causing liver damage. The first is the sparing of the kidneys, although Combes, Stastny, Shorey, Eigenbrodt, Barrera, Hull, and Carter (1971) describe a single case of glomerulonephritis (with complexes in the kidney). The second is the irregular occurrence of the clumps. For instance, antigen was clumped in 13 of 67 specimens examined in the Virus Reference Laboratory without added antiserum. Five of these were from patients with acute hepatitis, one from chronic hepatitis, two from blood donors, and five from dialysis unit patients. Of the patients with scattered antigen, 34 had acute hepatitis, nine were carriers and 11 were dialysis patients (Field, 1971). Thirdly there has been no clear demonstration that these clumps can actually be split to yield Australia antigen and antibody, and the finding of the latter ir hepatitis patients'sera is quite exceptional.

Attempts to assess the role of cellular immunity in serum hepatitis have also yielded equivocal results. Lymphocytes from the peripheral blood of patients long recovered from serum hepatitis might be expected to transform on exposure to Australia antigen in vitro, but the one study which did show this response (Laiwah, 1971) has not yet been confirmed. The agent could not be propagated in 'normal' human lymphocytes with or without concurrent stimulation with phytohaemagglutinin (Millman, Zavatone, Gerstley, and Blumberg, 1971).

After acute serum hepatitis complete recovery is the rule. Both the antigen titre and the serum transaminase levels tend to fluctuate, but three months after the onset of jaundice the antigen is usually undetectable by the usual laboratory tests and the transaminase level is within normal limits. In a comparison of a large series of healthy persons with and without a prior history of 'jaundice', Soulier, Courouce-Pauty, and Benamon-Djiane (1970) found almost identical rates of Australia antigen carriage in the two groups. Nevertheless, progression from acute antigen-positive hepatitis to chronic active hepatitis and even cirrhosis has occasionally been observed.

The humoral response to serum hepatitis infection is not understood. Individuals repeatedly exposed to the agent, for example by multiple transfusions, sometimes produce antibody (IgG) which reacts with Australia antigen in gel diffusion, immunoelectrophoresis, complement-fixation, and immune adherence tests. These people may or may not have suffered a clinical infection. Patients convalescent from serum hepatitis rarely produce anti-Australia antibody which can be measured by these tests. Newer tests such as radioimmunoassay (Walsh, Yalow, and Berson, 1970) and passive haemagglutination (Vyas and Shulman, 1970) measure much lower concentrations of anti-Australia antibody. It seems that even low levels of antibody are not regularly formed after infection, although they are to be found in about 10 to $20 \%$ of the general population (Lander, Alter, and Purcell, 1971).

There is no information about the relation of this antibody and immunity to subsequent infection, but in this context it may be significant that normal human immunoglobulin does not protect against serum hepatitis. Very limited studies do, however, suggest that immunoglobulin made from plasma containing measurable amounts of anti-Australia antibody may be protective (Soulier et al, 1972). There has also been one attempt to stimulate active immunity to serum hepatitis by inoculating heattreated serum containing Australia antigen. This has met with partial success (Krugman, Giles, and Hammond, 1971) but it is uncertain whether this was due simply to stimulation of anti-Australia antibody or whether attenuated infection had resulted.

It is difficult to compare this confused situation with that of lymphocytic choriomeningitis where formation of neutralizing antibody occurs very late in infection (Hotchin, Benson, and Sikora, 1969) and killed vaccines are ineffective (Milzer and Levinson, 1946).

\section{Chronic Liver Disease}

In Britain it is unusual to encounter Australia antigen in serum from a patient with chronic active hepatitis, biliary or portal cirrhosis, or hepatoma. In the Virus Reference Laboratory during 1971, 99 cases of chronic liver disease were examined and only $6 \%$ were positive. In countries where carriers are common, chronic liver disease with Australia antigen is also common. This raises the question of how many more might be detected if much more sensitive tests were available. If the disease follows thelymphocytic choriomeningitis pattern, virus antigen levels might be expected to be rather high and in all of the positive patients mentioned above antigen was detected even by the relatively insensitive gel diffusion test. It is of interest to note that despite very long- 


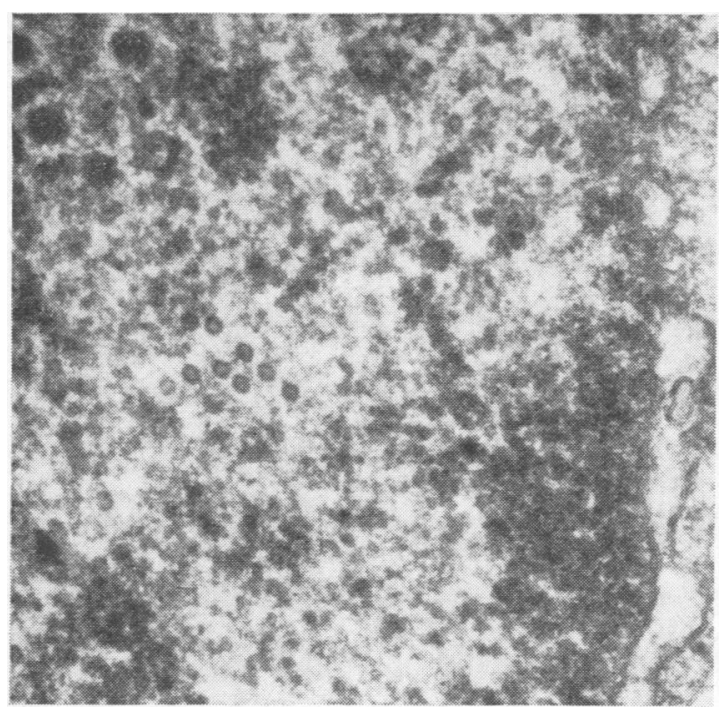

Fig. 3 Portion of a liver parenchyma from a patient with chronic active hepatitis and Australia antigen in the serum. The nuclear membrane runs across the top of the field and the nucleoplasm contains a group of nine round particles (centre) each about $23 \mathrm{~nm}$ diameter. $\times 82000$ (electron micrograph by courtesy of Dr E. J. Wills).

term antigenic stimulus anti-Australia antibody is rarely found in these patients. It was not demonstrable in any of the 99 cases of chronic hepatitis tested in the Virus Reference Laboratory during 1971.

There is some evidence for the persistence of the infective agent itself in chronic liver disease. Not only could Stokes (1954) transmit infection using serum as inoculum, but the small virus-like particles described in acute hepatitis have also been found in a case of chronic active hepatitis (Figure 3; Wills, 1971)

\section{Hepatitis Carriers}

High titres of both serum hepatitis virus and of Australia antigen may persist in the blood of some healthy individuals for many years (Zuckerman and Taylor, 1969), while in others the carrier state may be of quite short duration or even intermittent (Cossart, 1972). Are carriers undergoing an enormously prolonged incubation period which, it might be supposed, could be activated into acute illness by some appropriate event? On the other hand is the carrier state in reality subclinical, chronic, or even acute hepatitis in these apparently healthy people? Thirdly, are these individuals either immunologically deficient, or specifically tolerant to serum hepatitis because they acquired infection in utero or very early in lif $\epsilon$ ?
The age distribution of Australia antigen carriage has been determined only in high incidence areas such as Japan (Okochi and Murakami, 1968) where the rate is very low in childhood, reaches a maximum of $10 \%$ in young adult life, and then falls gradually with increasing age. This would be consistent either with the occasional persistence of infection or with indefinite prolongation of the incubation periods, since clinically acute infection is commonest in young adults.

Neither liver function tests nor liver biopsies (Klinge, Kaboth, and Arnold, 1971) have yielded clear evidence of liver disease in hepatitis carriers, nor have they entirely excluded it. Long-term studies of large numbers are needed to assess the significance of Australia antigen carriage for the individual.

The transmission of lymphocytic choriomeningitis infection from mother to offspring in utero is followed by the establishment of specific immune tolerance to that agent (Traub, 1936). Prospective studies of Australia antigen carriers in pregnancy so far show that hepatitis is not transmitted to the infant in this way. When acute antigen-positive hepatitis occurs early in pregnancy the outcome is also benign, but should hepatitis occur about the time of delivery, there is a substantial risk that the baby will be infected (Cossart, 1972). The cord blood of these infants has in all the instances so far reported been Australia antigen negative, and antigen has appeared after an interval of about three weeks. A similar interval was observed in a baby who had been transfused with antigen-positive blood on the day of delivery. In these affected infants liver disease does not become evident for some weeks or months, but many develop a low-grade chronic hepatitis and remain long-term antigen carriers (Wright, Perkins, Bower, and Jerrome, 1970). It does not seem likely that infection in utero or in infancy results in the establishment of lifelong hepatitis carriage in a significant number of persons.

\section{Hepatitis and Immunosuppression}

In persons naturally immunodeficient, such as mongols, uraemic patients or lepromatous lepers, as well as in those artificially immunosuppressed, serum hepatitis is modified in two ways (London et al, 1969). First the liver damage tends to be slight and often passes unnoticed. Secondly the time scale of the infectious process is greatly prolonged. The viraemic phase of the incubation period may last weeks or months but the most striking feature is the persistence of viraemia for months or years with minimal abnormality of the liver function tests (Polakoff, Cossart, Tillett, 1972). Liver biopsies at this stage show evidence of low-grade activity, and a 
recent paper (Huang, 1971) reports the presence of the small 'virus' particles in the parenchymal cells. The titre of Australia antigen and of infectivity in the serum remains high and the antigen particles are seldom seen in clumps. This effect of immunosuppression on serum hepatitis infection is quite similar to its effects on lymphocyte choriomeningitis.

The picture of serum hepatitis presented in this paper is based mainly on indirect evidence provided by Australia antigen studies and is sure to require modification when methods of cultivating the agent and measuring immunity become available. This paucity of information contrasts greatly with the voluminous literature about lymphocytic choriomeningitis although the persistent nature of both infections was recognized more than 30 years ago. There seems to be an underlying similarity between the pathological mechanism in the two diseases, although it is unlikely that the agents belong to the same virus group.

\section{References}

Almeida, J. D., and Waterson, A. P. (1969). Immune complexes in hepatitis. Lancet, 2, 938-986.

Almeida, J. D., Zuckerman, A. J., Taylor, P. E., and Waterson, A. P. (1969). Immune electron microscopy of the Australia-SH (serum hepatitis) antigen. Microbios., 2, 117-123.

Apostolov, K., Bauer, D. J., Selway, J. W. T., Fox, R. A., Dudley, F. J., and Sherlock, S. (1971). Australia antigen in urine. Lancet, 1, 1274-1275.

Barker, L. F., Shulman, N. R., Murray, R., Hirschman, R., Ratner, F., Diefenbach, W. C. L., and Geller, H. M. (1970). Transinission of serum hepatitis. J. Amer. med. Ass., 211, 1509-1512.

Barker, L. F., Smith, K. O., Gehle, W. D., and Shulman, N. R. (1969). Some antigenic and physical properties of virus-like particles in sera of hepatitis patients. J. Immunol., 102, 1529-1532.

Bayer, M. E., Blumberg, B. S., and Werner, B. (1968). Particles associated with Australia antigen in the sera of patients with leukaemia, Down's syndrome and hepatitis. Nature (Lond.), 218, 1057-1059.

Blumberg, B. S., Alter, H. J., and Visnich, S. (1965). A 'new' antigen in leuks ma sera. J. Amer. med. Ass., 191, 541-546.

Cherubin, C. E. (1971). Risk of post-transfusion hepatitis in recipients of blood containing SH antigen at Harlem hospital. Lancet, 1, 627-630.

Combes, B., Stastny, P., Shorey, J., Eigenbrodt, E. H., Barrera, A. Hull, A. R., and Carter, N. W. (1971). Glomerulonephritis with deposition of Australia antigen-antibody complexes in glomerular basement membrane. Lancet, 2, 234-237.

Cossart, Y. E. (1972). Australia antigen and the human foetus. Amer. $J$. Dis. Child., in press.

Cossart, Y. E., and Field, A. M. (1970). Virus-like particles in serum of patients with Australia antigen-associated-hepatitis. (Letter to the Editor). Lancet 1, 848 .

Dane, D. S., Cameron, C. H., and Briggs, M. (1970). Virus-like particles in serum of patients with Australia antigen-associated hepatitis. Lancet, 1, 695-698.

Drake, M. E., Barondess, J. A., Bashe, W. J., Jr., Henle, G., Henle, W., Stokes, J., Jr., and Pennell, R. B. (1953). Failure of convalescent gamma, globulin to protect against homologous serum hepatitis. J. Amer. med. Ass., 152, 690-693.

Field, A. M (1971). Unpublished observations.

Findlay, G. M., and Stern, R. O. (1936). Pathological changes due to infection with the virus of lymphocytic choriomeningitis. J. Path. Bact., 43, 327-338.

Gerin, J. L., Purcell, R. H., Hoggan, M. D., Holland, P. V., and Chanock, R. M. (1969). Biophysical properties of Australia antigen. J. Virol., 4, 763-768.

Grob, P. J., and Je:nelka, H. (1971). Faecal SH (Australia) antigen in acute hepatitis. Lancet, 1, 206-208.
Gust, I. D., Kaldor, J., and Nastasi, M. (1971). Absence of Au antigen in faeces of patients with Au positive sera. (Letter to the Editor). Lancet, 1,797.

Hotchin, J. (1971). Persistent and Slow Viius Infections. (Monographs in Virology, 3). Karger, Basle.

Hotchin, J., Benson, L. M., and Sikora, E. (1969). Detection of neutralizing antibody in lymphocytic choriomeningitis virus in mice. J. Immunol., 102, 1128-1135.

Huang, S. N. (1971). Hepatitis-associated-antigen hepatitis. Amer. J. Path., 64, 483-500.

Józwiak, W., Košcielak, J., Madaliński, K., Brzosko, W. J., Nowosławski, A., and Kloczewiak, M. (1971). RNA of Australia antigen. Nature New Biol., 229, 92-94.

Klinge, O., Kaboth, U., and Arnold, R. (1971). Liver histology in healthy carriers of Australia-SH antigen or antibodies. Germ. Med., 1, 4-5.

Krugman, S., Giles, J. P., and Hammond, J. (1971). Viral hepatitis: type B (MS-2 strain). Studies on active immunization.J. Amer. med. Ass., 217, 41-45.

Laiwah, A. A.C. Y. (1971). Lymphocytic transformation by Australia antigen. Lancet, 2, 470-471.

Lander, J. J., Alter, H. J., and Purcell, R. H. (1971). Frequency of antibody to hepatitis associated antigen as measured by a new radioimmunoassay technique. J. Immunol., 106, 1166-1171.

Lucké, B. (1944). The patholegy of fatal epidemic hepatitis. Amer. J. Path., 20, 471-593.

McCollum, R. W. (1952). The size of serum hepatitis virus. Proc. Soc. exp. Bi l. $_{\text {. }}$ N.Y. $., 81,157-160$.

Millman, I., Agarwal, S. S., Bugbee, S. J., Blumberg, B. S., and Loeb, L. A. (1971). Lymphocyte transformation and hepatitis. II. Lack of direct in vitro inhibition by purified Australia antigen. Proc. Soc. exp. Biol. (N.Y.), 138, 198-203.

Millman, I., Zavatone, V., Gerstley, B. J. S., and Blumberg, B. S. (1969). Australia antigen detected in the nuclei of liver cells of patients with viral hepatitis by the fluorescent antibody technique. Nature (Lond)., 222, 181-184.

Milzer, A., and Levinson, O. (1946). Production of potent inactivated vaccines with U.V. radiation. V. Active and passive immunization with lymphocytic choriomeningitis vaccine (Abstr.) $J$. Bact., 51, 622.

Murray, R., Diefenbach, W. C. L., Ratner, F., Leone, N. C., and Oliphant, J. W. (1954). Carriers of hepatitis in the blood and viral hepatitis in whole blood recipients. II. Confirmation of carrier state by transmission experiments in volunteers. $J$. Amer. med. Ass., 154, 1072-1074.

Nielsen, J. O., and Elling, P. (1971). Investigations of liver biopsies for Australia antigen by immunofluorescent technique. Clin. exp. Immunol., 9, 699-705.

Nowoslawski, A., Brzosko, W. J., Madaliński, K., and Krawczyński, K. (1970). Cellular localization of Australia antigen in the liver of patients with lymphoproliferative disorders. Lancet, 1, 494-498.

Nowosławski, A., Swiderska, H., Madaliński, K., Krawczyński, K., and Brzosko, W. J. (1971). Inflammatory effect of Au antibody immune complexes. Lancet, 1, 398.

Okochi, K., and Murakami, S. (1968). Observation on Australia antigen in the Japanese. Vox Sang. (Basel), 15, 374-385.

Polakoff, S., Cossart, Y. E., Tillett, H. F., and Collaborators (1972). Hepatitis in dialysis in the United Kingdom. To be published 1972

Prince, A. M. (1968). An antigen detected in the blood during the incubation period of serum hepatitis. Proc, nat. Acad. Sci. (Wash.), 60, 814-821.

Scotto, J., Stralin, H., and Caroli, J. (1971).Etude de Particules d'aspect viral et de lésions ultrastructurales variées dans des hépatites virales essentiellement graves: rappaport avec l'antigéne Australia. Path. et Biol., 19, 489-495.

Shulman, N. R., and Barker, L. F. (1969). Virus-like antigen, antibody, and antigen-antibody complexes in hepatitis measured by complement fixation. Science., 165, 304-306.

Soulier, J. P. et al (1972). Prevention of hepatitis and virus B. Amer. J. Dis. Child., in press.

Soulier, J. P., Courouce-Pauty, A. M., and Benamon-Djiane, D. (1970). Study of the Australia antigen and of the corresponding antigen in blood donors in Paris. Vox. Sang. (Basel), 19, 345351 .

Stokes, J., Jr., Berk, J. E., Malamut, L. L., Drake, M. E., Barondess, J. A., Bashe, W. J., Wolman, I. J., Farquhar, J. D., Bevan, B., Drummond, R. J., Maycock, W. d'A., Capps, R. B., and 
Bennett, A. M. (1954). The carrier state in viral hepatitis. J. Amer. med. Ass., 154, 1059-1065.

Traub, E. (1936). Persistence of lymphocytic choriomeningitis virus in immune animals and its relation to immunity. J. exp. Med., 63, 847-861.

Tripatzis, I., and Horst, H. G. (1971). Detection of Australia SH antigen in urine. Nature (Lond.), 231, 266-267.

Vyas, G. N., and Shulman, N. R. (1970). Hemagglutination assay for antigen and antibody associated with viral hepatitis. Science, 170, 332-333.

Walsh, J. H., Yalow, R. S., and Berson, S. A. (1970). Radioimmuno- assay of Australia antigen. Vox Sang. (Basel), 19, 217-224.

Wills, E. J. (1972). Electron microscopy of the liver in glandular fever hepatitis and cytomegalovirus virus hepatitis. Amer.J. Dis. Child., in press.

Wills, E. J. (1971). Unpublished observations.

Wright, R., Perkins, J. R., Bower, B. D., and Jerrome, D. W. (1970). Cirrhosis associated with the Australia antigen in an infant who acquired hepatitis from her mother. Brit. med. J., 4, 719-721.

Zuckerman, A. J., and Taylor, P. E. (1969). Persistence of the serum, hepatitis (SH-Australia) antigen for many years. Nature (Lond.), 223, 81-82. 